\title{
Er det overvekt eller vektfokus som er helseskadelig?
}

\author{
Overvekt og fedme beskrives som en global epidemi og en alvorlig kronisk sykdom med store konsekvenser, \\ også for Norge. Stemmer det, eller står vi overfor en konstruert helserisiko der sterke interesser gjør forret- \\ ning på folks oppmerksomhet på vekt og kropp?
}

Ifølge gjeldende klassifisering har en person med kroppsmasseindeks (BMI) $\geq 25$ «diagnosen» overvekt. Det innebærer at over halvparten av norske 40-50 åringer og ett av seks barn defineres som overvektige eller fete (fete $=$ BMI $\geq 30$ ) med betydelig økt risiko for vektrelatert tilleggssykdom. Helsemyndighetene innrømmer at det å løfte frem en vekt som «sunn» kan virke stigmatiserende og gi unødvendig søkelys på risikoer (1). Kunnskapsoppsummeringer bekrefter at overvektige og fete opplever omfattende stigmaer $i$ arbeidsliv, helsevesen, medier, i sosiale relasjoner og under utdanning (2). Det er for eksempel en vanlig oppfatning at fete mennesker er skyld i egen dårlige helse og tar helseressurser fra andre med mer «plettfri vandel» (3).

Forbindelsen mellom vekt og stigma kan begynne tidlig i livet. Å få merkelappen «overvektig» $\mathrm{i}$ tenårene har vist seg å være en signifikant prediktor for fedme i tidlig voksen alder uavhengig av BMI som tenåring, foreldres inntekt og utdanning, rase og alder for menarken (4). Vekt- og kroppsmisnøye er utbredt blant ungdom, spesielt blant jenter. Selv små avvik fra kroppsidealet kan gi misnøye med egen kropp og forsøk på å slanke seg $(5,6)$. Det er sterk sammenheng mellom kroppsmisnøye og redusert selvvurdert helse hos tenåringer (5). Redusert selvvurdert helse i ungdommen er videre en viktig prediktor for allostatisk overbelastning og redusert subjektiv helse i tidlig voksen alder (7).

I en oversiktsartikkel har Campos og medarbeidere kritisk vurdert noen av de påstander som florerer i levevanefeltet knyttet til overvekt og fedme (8). Dokumentasjonen på sammenhengen mellom vekt og redusert helse er på ingen måte entydig.

Overvekt gir økt risiko for tidlig død! Den første påstandenvi tar for oss er at overvekt gir økt risiko for tidlig død. Sammenhengen mellom vekt og helserisiko er avhengig av hvilken BMI det refereres til. Ved ekstrem under- eller overvekt er BMI en svak prediktor for dødelighet $(8,9)$. Derimot viser en metaanalyse basert på nesten 100 epidemiologiske studier og tre millioner deltakere, en $6 \%$ redusert risiko for død hos personer som er klassifisert som «overvektige» (BMI 25-29,9) og 5\% redusert risiko hos personer med «fedme» grad 1 (BMI 30-34) i forhold til «normalvektige» (BMI 18-24) (10). Konklusjonene er ikke nye: Personer med overvekt eller moderat fedme lever like lenge og ofte lenger enn «normalvektige» $(11-13)$.

Ved noen sykdommer er fedme forbundet med høyere levealder. Dette kalles for fedmeparadokset (the obesity paradox). Fete personer med diabetes, høyt blodtrykk, hjerte- og karsykdom og kronisk nyresvikt lever lenger enn tynne personer med disse sykdommene (14). Fete personer med hjerteinfarkt og som

\section{«Vi anbefaler i stedet et perspektiv som byg- ger på grunnleggende respekt for alle kropps- størrelser og fasonger»}

har gjennomgått koronar bypass, angioplastikk eller hemodialyse lever lenger enn tynnere personer med samme problematikk. Eldre overvektige lever lenger enn slankere eldre.

\section{Overvekt gir økt risiko for sykdom!}

Vekt har sammenheng med noen sykdommer, men årsaksforholdet er mer komplisert. Med unntak av artrose og noen få typer kreft er kausale forbindelser mellom fedme og sykdom hypotetiske (8). Andre faktorer som kan forklare sammenhengen mellom vekt og sykdom er fysisk form, aktivitet, kosthold, jojo-slanking, sosioøkonomisk status, diskriminering, kroppsmisnøye, søvn og kronisk stress (15). Når det kontrolleres for dette, reduseres risikoen forbundet med fedme eller den forsvinner helt. For eksempel forklarte jojo-slanking den økte risikoen i Framingham-studien (16) og National Health and Nutrition Examination-studien (17). Denne type slanking fører til inflammasjon og økt risiko for mange vektrelaterte sykdommer (18). Forskning gjennom 25 år viser at jojoslanking er uløselig knyttet til dårligere fysisk helse og velvære $(9,14)$ og dødelighet (19).

Det er sannsynlig at faktorer som øker risiko for sykdom samtidig øker risiko for overvekt $(8,14)$. Fedme kan like gjerne være et tidlig symptom på sykdom heller enn den underliggende årsaken. Når studier viser at vekttap gir helsegevinst, kan det skyldes endring i levevaner. Fysisk aktivitet er en bedre prediktor for hjerte- og karsykdom enn BMI. Fete personer som går raskt 30 minutter hver dag har lavere risiko for tidlig død enn slanke i dårlig fysisk form og samme risiko som slanke mennesker i god fysisk form (20).

\section{Vekttap bedrer helsen!}

Gitt at det hypotetisk sett er en sterk korrelasjon mellom overvekt og sykdom/tidlig død og at denne sammenhengen er kausal, er det så mulig å redusere vekten med diett og økt aktivitet? Svaret er «nei» for de aller fleste. Riktignok mister man vekt på kort sikt, men de fleste legger på seg igjen over 3-5 år selv om de vedlikeholder diett og trening. For å vedlikeholde en ny vekt må personen spise færre kalorier og/eller forbrenne flere kalorier enn tidligere resten av livet $(9,21)$. Eksperter diskuterer om problemet med å vedlikeholde en redusert vekt best forklares ved biologi, atferd eller trekk ved omgivelsene (22). Det man imidlertid er enige om er at vektøkning er relativt lett og vekttap vanskelig. Vår kontroll over vekten er med andre ord begrenset $(15,23,24)$.

Påstanden om at overvektige og fete personer får bedre helse ved å slanke seg til «normal» vekt er en utestet hypotese. Ingen studier kan vise til slike langtidsresultater på en gruppe mennesker. Flere studier viser riktignok bedre helse knyttet til små endringer i vekt (5-10\% nedgang). Imidlertid er resultatene knyttet til intervensjoner der deltakerne også endrer levevaner, spiser sunnere og øker aktiviteten. Dette er levevaner som vi vet påvirker helsen uavhengig av vekten (25). I Look AHEAD-studien undersøkte man om vekttap som følge av intensiv livsstilsendring reduserte risiko for hjerte- og karsykdom og tidlig død hos overvektige og fete deltakere med diabetes type 2 . Den randomiserte kontrollerte studien skulle vare 13,5 år, men ble stoppet etter ti år. Det var da 2,5 \% vektforskjell mellom intervensjons- og kontrollgruppen, men ingen forskjell i sykelighet og dødelighet mellom gruppene $(26,27)$.

Så kan man spørre seg om det spiller noen rolle om man anbefaler vektreduksjon via sunn kost og økt aktivitet eller om man anbefaler metodene fordi de er helsefremmende i seg selv? I tillegg til at vi nå vet at mange overvektige og fete ikke blir slankere av sunn kost og økt aktivitet, risikerer vi å overbehandle såkalte «overvektige» 
og «fete» som allerede har sunne levevaner. På samme måte risikerer vi å overse mange «normale» eller slanke personer som vil ha nytte av å endre levevaner.

\section{Helse uavhengig av vekt}

Helsen kan bedres gjennom et sunnere levesett uavhengig av om vekten reduseres. Med støtte i forskningen vi har oppsummert i denne artikkelen, mener vi at å vektlegge vektens betydning for helse er skadelig for folk flest. Mange søker vektreduksjon gjennom skadelige metoder: røyking, oppkast, jojo-slanking, stadig nye dietter, slankepiller og kirurgi. Videre er et vekttap ikke mulig å vedlikeholde over tid. Vektreduksjon bidrar til vektøkning på sikt, med påfølgende stigmatisering og diskriminering. Det er derfor uetisk å forsvare en praksis som medfører mer skade enn nytte $(9,25,28)$.

Vi anbefaler i stedet et perspektiv som bygger på grunnleggende respekt for alle kroppsstørrelser og fasonger, et perspektiv som bidrar til kroppsaksept og redusert stigma. Det er flere modeller som bygger på et slikt syn. En holistisk modell som har økende betydning internasjonalt er «Health at every size» (HAES) $(9,15)$.

\section{Gro Beate Samdal \\ gro.samdal@igs.uib.no \\ Eivind Meland}

Gro Beate Samdal (f. 1958) er sykepleier og ph.d.-stipendiat ved Universitetet i Bergen. Ph.d.-prosjektet omhandler helsefremming ved frisklivssentralene.

Forfatter har fylt ut ICMJE-skjemaet og oppgir følgende interessekonflikter: Ph.d.-prosjektet er finansiert av Forskningsrådet.

Eivind Meland (f. 1950) er spesialist i allmennmedisin, fastlege og professor ved Universitetet i Bergen.

Forfatter har fylt ut ICMJE-skjemaet og oppgir ingen interessekonflikter.

\section{Litteratur}

1. Helsedirektoratet. Forebygging, utredning og behandling av overvekt og fedme hos voksne. www helsedirektoratet no/publikasjoner/ nasjonal-faglig-retningslinje-for-forebyggingutredning-og-behandling-av-overvekt-og-fedmehos-voksne/Sider/default.aspx (4.5.2014).

2. Puhl RM, Heuer CA. The stigma of obesity: a review and update. Obesity (Silver Spring) 2009; 17: $941-64$

3. Malterud K, Ulriksen K. «Norwegians fear fatness more than anything else» - a qualitative study of normative newspaper messages on obesity and health. Patient Educ Couns 2010: 81: 47-52.

4. Hunger JM, Tomiyama AJ. Weight labeling and obesity: a longitudinal study of girls aged 10 to 19 years. JAMA Pediatr 2014; 168: 579-80.

5. Meland E, Haugland S, Breidablik HJ. Body image and perceived health in adolescence. Health Educ Res 2007; 22: 342-50.

6. Dyremyhr AE, Diaz E, Meland E. How adolescent subjective health and satisfaction with weight and body shape are related to participation in sports. J Environ Public Health 2014; 2014: 851932.

7. Vie TL, Hufthammer KO, Holmen TL et al. Is selfrated health a stable and predictive factor for allostatic load in early adulthood? Findings from the Nord Trøndelag Health Study (HUNT). Soc Sci Med 2014; 117: 1-9.

8. Campos P, Saguy A, Ernsberger P et al. The epide miology of overweight and obesity: public health crisis or moral panic? Int J Epidemiol 2006; 35: $55-60$.

9. Tylka TL, Annunziato RA, Burgard D et al. The weight-inclusive versus weight-normative approach to health: Evaluating the evidence for prioritizing well-being over weight loss. Int J Obes 2014: 2014: 18

10. Flegal KM, Kit BK, Orpana $\mathrm{H}$ et al. Association of all-cause mortality with overweight and obesity using standard body mass index categories: a systematic review and meta-analysis. JAMA 2013. 309: $71-82$

11. Flegal KM, Graubard BI, Williamson DF et al. Excess deaths associated with underweight, overweight, and obesity. JAMA 2005; 293: 1861-7.

12. Durazo-Arvizu RA, McGee DL, Cooper RS et al. Mortality and optimal body mass index in a sample of the US population. Am J Epidemiol 1998; 147: 739-49.

13. Troiano RP, Frongillo EA Jr, Sobal J et al. The relationship between body weight and mortality: a quantitative analysis of combined information from existing studies. Int J Obes Relat Metab Disord 1996: 20:63-75

14. Bacon L, Aphramor L. Weight science: evaluating the evidence for a paradigm shift. Nutr J 2011; 10: 9

15. Bacon L. Health at every size: The surprising truth about your weight. Dallas, TX: BenBella Books, 2010

16. Lissner L, Odell PM, D'Agostino RB et al. Variability of body weight and health outcomes in the
Framingham population. N Engl J Med 1991; 324 : 1839-44

17. Diaz VA, Mainous AG 3rd, Everett CJ. The association between weight fluctuation and mortality: results from a population-based cohort study. J Community Health 2005; 30: 153-65.

18. Strohacker K, McFarlin BK. Influence of obesity, physical inactivity, and weight cycling on chronic inflammation. Front Biosci (Elite Ed) 2010; 2: 98-104.

19. Klenk J, Rapp K, Ulmer H et al. Changes of body mass index in relation to mortality: results of a cohort of 42,099 adults. PLoS ONE 2014; 9: e84817.

20. Farrell SW, Braun L, Barlow CE et al. The relation of body mass index, cardiorespiratory fitness, and all-cause mortality in women. Obes Res 2002; 10 : 417-23.

21. Mann T, Tomiyama AJ, Westling E et al. Medicare's search for effective obesity treatments: diets are not the answer. Am Psychol 2007; 62: 220-33.

22. Cawley J. The Oxford handbook of the social science of obesity. Oxford: Oxford University Press 2011

23. Sumithran P, Proietto J. The defence of body weight: a physiological basis for weight regain after weight loss. Clin Sci (Lond) 2013; 124 : 231-41.

24. Maclean PS, Bergouignan A, Cornier MA et al. Biology's response to dieting: the impetus for weight regain. Am J Physiol Regul Integr Comp Physiol 2011; 301: R581-600

25. Campos P. Does fat kill? A critique of the epidemiological evidence. I: Rich E, Monaghan L. Aphramor L, red. Debating obesity: Critical perspectives. Palgrave Macmillan, 2011: 36-59.

26. Wing RR, Bolin P, Brancati FL et al. Cardiovascular effects of intensive lifestyle intervention in type 2 diabetes. N Engl J Med 2013; 369: 145-54.

27. Davis NJ, Goswami G. Modest weight loss does not decrease cardiovascular morbidity and mortality in adults with type 2 diabetes. Evid Based Med 2014; 19: 64

28. Vartanian LR, Smyth JM. Primum non nocere: obesity stigma and public health. J Bioeth Inq 2013; 10: 49-57.

Mottatt 27.10. 2014, første revisjon innsendt 6.11. 2014, godkjent 14.11. 2014. Redaktør: Hanne Støre Valeur.

Publisert først på nett. 